\title{
The Training Program of Application-oriented Finance and Economics Colleges Based on "2 +1" Training Model ---- A Case Study of the Accounting Major
}

\author{
Kening $\mathrm{HaO}^{1,}$, , Tingshan Song ${ }^{2}$, Peihai Wei ${ }^{3,}, \mathrm{Hui} \mathrm{Li}^{4,}$ \\ 1,2,3,4 Department of Economics, Qilu Normal University, Jinan ,250013,China \\ ${ }^{\mathrm{a} E}$-mail: keningsde@163.com
}

Keywords: Practice education; Training model; Training program; Practical teaching

\begin{abstract}
It is a feasible choice for application-oriented finance and economics colleges to choose "2+1" training mode. It is the implementation of the "Opinions on Further Strengthening the College Practice Education Work" jointly issued by the Ministry of Education and other seven ministries. In the model, "+1" refers to the practice during the last academic year; "2" means the theory course in four semesters of the first two years, $2 / 3$ of which is for the course, and 1/3 of which for the practice; In the design of training program, we encourage the students to improve their qualifications, actively promote the "double certificates" system; set module courses and optional courses, and implement mutual recognition of credit, not to increase the burden of students. It helps to improve the students' comprehensive qualities and employment competitiveness.
\end{abstract}

\section{Significance of the Project}

On January 10th, 2012, the Ministry of Education and other seven ministries jointly came up with "Several Opinions on Further Strengthening the Practical Education in Colleges and Universities, " pointing out: "strengthen practical teaching......colleges and universities should make practical teaching standards respectively combined with the major features and requirements of personnel training, increase the proportion of practical teaching to ensure that the humanities and social sciences undergraduate programs takes not less than $15 \%$ of the total credits (hours), engineering, agriculture and medicine undergraduate takes not less than $25 \%$, higher vocational takes not less than $50 \%$, normal education practice takes not less than one semester, postgraduate of professional degree takes not less than six months;" " deepen the reform of practical teaching method" "carry out social practice activities systematically......each undergraduate students should take at least four weeks to participate in social practice during the academic years, postgraduate students, vocational students at least two weeks, each student during the academic years should attend at least one social survey and write a report;" "focus on strengthening the building of the practical education team; " "strengthen the construction of practical education bases[1].

To improve students' ability of application, innovation and employability, conscientiously implement "Several Opinions on Further Strengthening the Practical Education in Colleges and Universities" jointly issued by the Ministry of Education and other seven ministries, we seek to explore a set of professional training model and training program of finance and economics applied to the ordinary local colleges and universities.

The practical significance of the research lies in the practical guidance to the teaching reform and the choice of the training mode in the Application-oriented Finance and Economics Colleges. It can provide the training mode, training programs, teaching programs, training room construction, internship system and the standard of double card grafting operation[2].

\section{Training Mode Choice}

To implement "Several Opinions on Further Strengthening the Practical Education in Colleges and Universities" jointly issued by the Ministry of Education and other seven ministries and achieve the requirements that "the practical teaching accounted for not less than $50 \%$ ", the training mode of " $2+1$ " is more practical choice. This is because " +1 " in the mode refers to the practice during the last academic year which makes the practical teaching take 33\%; "2" means the theory course in 
four semesters of the first two years, $2 / 3$ of which is for the course, and 1/3 of which for the practice; military training, enrollment and finishing education, employment guidance, employment and work-study program, social investigation, curriculum practice, all of these together can meet the requirements of the Ministry of Education. So we design the following training program, to ensure the smooth implementation of the " $2+1$ " training mode.

\section{Training program design}

A. Introduction of the Training Program

The training program is made of focusing on the relevant requirements of the practical teaching, trying to change the concept of valuing theory more than practice and valuing knowledge more than capacity, insisting on the ability training to enrich social practice. Practical teaching is added to the teaching programs and the proportion is increased, in order to improve the students' ability of learning, practice and innovation. The main features of the training program are as follows:

1. " $2+1 "$ mode is adopted in training

"2 +1" mode refers to two years of theory learning and one year of graduation practice in the three years of college education.

2. Various practice forms

The practice forms mainly include course practice, internship, job training, graduation practice, graduation design, social surveys, military training and other forms.

3. Strengthen the practical teaching

In addition to the final year of graduation practice, the practical teaching during the school years is as follows: The freshmen are expected to participate in the two-week military training and enrollment education; Most of the professional courses contain one hour of practical teaching in the semester; In the first two years, the total internship time is required not less than two months (176 hours); During the academic years, each student is required to take part in at least one social survey and write an investigation report; Graduation internship is scheduled in 1-12 weeks of the sixth semester; graduate design is scheduled in 13-16 weeks of the sixth semester.

4. To encourage students' academic promotion, and actively promote the "double certificates" system

The curriculum setting of each semester tries to take the vocational qualification certificate examination and self-study undergraduate examination which are associated with the major into account, to encourage the students to participate in these examinations by accepting their test scores. It would help the students upgrade their qualifications and improve the employability and competitiveness.

5. Mutual credits recognition system

In each semester, the students are required to have module courses of 10 credits and optional courses of 10 credits per semester except for the compulsory courses. Mutual credits recognition system is adopted in the evaluation of learning achievement of different types. For the students who need a vocational qualification certificate, certificate examination equals the score of elective course; For the students who take the self-study undergraduate examination, the score of the examination equals the score of elective course; For the students of the feature classes (such as school-enterprise cooperation classes, services outsourcing), the score of special courses (such as customer service, business etiquette in public relations, service outsourcing, team management, contact center operations management, etc.) equals the score of elective course.

B. Academic structure and graduation credits

Duration: 3 years (2+1 mode).Total Hours: 3008 hours (1496 hours of theory lectures, 576 hours of practical teaching and 936 hours of other practice).Credits required for graduation: 130 (66 credits for theory courses, 29 credits for practice, 35 credits for social practice).

C. Main courses

Preliminary higher mathematics, economics, management science, statistics, basic accounting, financial accounting, bank accounting, auditing, cost accounting, tax accounting, management 
accounting, computerized accounting, financial management, statistical analysis software, financial statement analysis and so on.

\section{Several key job description of the implementation of the program}

The implementation of the training program firstly needs the following points:

A. "2 $+1 "$ training mode is not our invention but the existing training mode of vocational colleges. While we really do a lot of bold attempts to enriched the " $2+1$ " training mode connotation combined with actual situation of the junior colleges. The implementation of " $2+1$ " training mode is a relatively large systems engineering. It not only needs a good training program, but also a lot of supporting work (such as the construction of teaching materials, the construction of teaching staff, the construction of internship bases, deep school-enterprise collaboration, the development and implementation of the practical teaching standards).

B. The development and implementation of the related practical teaching standards including the content and form of practical teaching, methods and standards of assessing the students and teachers and completion time and place[3].

C. The building and training of the teaching staff. Vigorously strengthen the construction of double-professionally-titled teachers[4] (see references); actively promote the implementation of the tutorial system. Each natural class is equipped with a full-time teacher as his mentor. The functions of the traditional teacher are transferred to the counselor, so that the mentor can spare more time to implement the " $2+1$ " training mode, help the students with their professional learning and practice, including double certificates learning, elective courses, personal development plan (make analysis and judgment whether to continue their studies or to work first and then continue their studies), social practices, job training, graduation practice.

D. Pay special attention to the construction of practice base to explore the way of deep school-enterprise cooperation[5] .The current employment situation is: on the one hand, students to land a job; on the other hand, it is difficult for the employer to recruit the talents, this is a situation of dilemma. On the one hand, we can make some adjustments in personnel training structure; on the other hand, we can provide some counseling and guidance for the students' ideas of choosing a job; further more we can make full use of the deep school-enterprise cooperation (such as school-enterprise win-win contract training, school-enterprise win-win feature classes, school-enterprise win-win training center building). For this program, we have reached of the feature classes sponsored by the enterprises with a number of enterprises; the related courses offered by the enterprises are inserted to the students' courses as their module coursed and optional courses.

\section{Acknowledgement}

This paper is supported by the following Fund programs to which the author is very grateful: (1) 2012 annual topic of National Business Education Research "Twelfth Five-Year Plan" (SKKT-12032); (2) 2012 annual university teaching reform project ordinary colleges and universities administered by the class of the High Commissioner for training mode selection and its Teaching Reform and Practice -A Case Study of Accounting Major"; (3) 2012 annual university teaching reform project "Research on teaching reform of economic management - A Case Study of Qilu Normal University"; (4) "12th five-year plan" of the vocational education and adult education in Shandong Province-one of the achievements of the 2012 annual project (2012zcj008).

\section{References}

[1] BBB"Several Opinions on Further Strengthening the Practical Education in Colleges and Universities" issued by Ministry of Education and other ministries (Ideological and Political Education[2012]1)

[2] Y.H. Liu, G.H. Chi, “Thirty years of Chinese accounting education reform: achievements, 
problems and countermeasures,” Accounting study, 2008(8)

[3] Z.H. Yao, Financial management and Accounting Education Reform, Southwestern University of Finance and Economics Press, 2011.08

[4] W.H. Xu, J.T. Wang, "A comparative study of Accounting Training Mode in Chinese and Foreign Universities”, Business economics, 2011 (15)

[5] M.Q.Sheng. Higher Accounting Education: Exploration and innovation , Economic Science Press, 2011.0. 